\title{
PROTECTION AND PROMOTION OF THE END USERS' RIGHTS OF PUBLIC ELECTRONIC COMMUNICATION SERVICES IN THE REPUBLIC OF MACEDONIA
}

\author{
Dafina Paunovska ${ }^{1}$, Valentina Angelkoska ${ }^{2}$, Aleksandar Risteski ${ }^{3}$ \\ ${ }^{1}$ Agency for Electronic Communications, Skopje, Republic of Macedonia \\ ${ }^{2}$ Faculty of Economics, University of Tourism and Management, Skopje, Republic of Macedonia \\ ${ }^{3}$ Faculty of Electrical Engineering and Information Technologies, \\ "Ss. Cyril and Methodius" University in Skopje, \\ Rugjer Bošković bb, P.O. box 574, 1001 Skopje, Republic of Macedonia \\ Dafina.Paunovska@aec.mk
}

\begin{abstract}
$\mathrm{A} \mathrm{b} \mathrm{s} \mathrm{t} \mathrm{r} \mathrm{a} \mathrm{c} \mathrm{t:} \mathrm{Telecommunications} \mathrm{are} \mathrm{one} \mathrm{of} \mathrm{the} \mathrm{fastest} \mathrm{growing} \mathrm{information} \mathrm{and} \mathrm{communication} \mathrm{technology}$ (ICT) industries in the world. Republic of Macedonia follows this trend and the growing development of the electronic communications services market has led to the initiation of a need for greater protection of consumers rights and promotion of the quality of services. Due to the lack of information about their rights, users are often subject to manipulation and abuse by providers of electronic communication services. The users of electronic communications services should be protected from the unfair practices of the companies that provide these services. Therefore, the EU has specific policies to protect consumers of telecommunications services, which include the right to free access to services and fair prices, and protection of the privacy of personal data. The EU Regulatory Framework for Electronic Communications is a series of rules that apply in the EU Member States. They encourage competition, improve market functioning and guarantee the basic rights of the user. The main goal is for European consumers to benefit from market liberalization that results in low prices, high quality and innovation in services. The results presented in this paper lead to a conclusion that by specifying the legal regulation in Macedonia and the mutual cooperation with the bodies that take care of the consumers rights in the field of electronic communications will contribute to faster, cost-effective legal procedures that will strengthen the legal safety of consumers.
\end{abstract}

Key words: electronic communications; consumer protection; end user rights; consumer organizations

\section{ЗАШТИТА И УНАПРЕДУВАЊЕ НА ПРАВАТА НА КРАЈНИТЕ КОРИСНИЦИ НА ЈАВНИ ЕЛЕКТРОНСКИ КОМУНИКАЦИСКИ УСЛУГИ ВО РЕПУБЛИКА МАКЕДОНИЈА}

А п с т р а к т: Телекомуникациите се една од најбрзо растечките информациски и комуникациски технологии (ИКТ) во светот. Република Македонија го следи овој тренд и сѐ поголемиот развој на пазарот на електронски комуникациски услуги доведе до иницирање на потреба од поголема заштита на правата на потрошувачите и промовирање на квалитетот на услугите. Поради недостаток на информации за нивните права, корисниците често се предмет на манипулација и злоупотреба од страна на давателите на електронски комуникациски услуги. Корисниците на електронските комуникациски услуги треба да бидат заштитени од неправедни практики на компаниите кои ги обезбедуваат овие услуги. Затоа ЕУ има специфични политики за заштита на потрошувачите на телекомуникациските услуги, кои вклучуваат право на слободен пристап до услуги и фер цени и заштита на приватноста на личните податоци. Регулаторната рамка на ЕУ за електронски комуникации претставува низа правила што важат во земјите-членки на ЕУ. Тие ја поттикнуваат конкуренцијата, го подобруваат функционирањето на пазарот и ги гарантираат основните права на корисникот. Главната цел е европските потрошувачи да имаат корист од либерализацијата на пазарот која резултира со ниски цени, висок квалитет и иновации во услугите. Истражувањето и резултатите презентирани во овој труд упатуваат на заклучок дека воведувањето на законската регулатива во Македонија и меѓусебната соработка со органите кои се грижат за правата на потрошувачите во областа на електронските комуникации ќе придонесат за побрзи, ефективни правни процедури кои ќе ја зајакнат правната безбедност на потрошувачите.

Клучни зборови: електронски комуникации; заштита на потрошувачи; права на крајни корисници; организации на потрошувачи 


\section{INTRODUCTION}

The European Commission's Progress Reports on Macedonia [1] indicate a continuous strengthening of the complaints system for the protection of consumer rights in electronic communications services. In accordance with the Law on Electronic Communications (LEC) [2-4], the Agency for Electronic Communications (AEC) [5] as a regulatory body in its work, in order to promote and develop the electronic communications market in Macedonia, takes into consideration the recommendations and standards of the European Commission and the European Union and the best world practices. In general, Macedonia has achieved a high degree of harmonization with the EU legislation in terms of protecting the rights of users of electronic communications services.

In order to ensure a high level of protection of the rights of consumers - users of public electronic communication services in Macedonia, there is a continuous process of adoption of appropriate legal regulations. In this respect, several laws that regulate this area have been adopted as following: Law on Electronic Communications [4], Law on Consumer Protection [6], Law on Personal Data Protection, Law on Protection of Competition, etc. The scope of the user's rights in the field of telecommunications is contained in chapter 13 of the LEC adopted in 2014, entitled "Rights of end users", and precisely one of the objectives of this Law, pursuant to Article 2 , line 3 , is protection of the rights of users, including end-users with disabilities and end-users with special social needs. Furthermore, in Article 20 of the Rulebook on the type and content of data that the operators of public communications networks and/or public communication service providers are obliged to publish in relation to the general conditions for access and use, prices and tariffs and quality parameters of the public communication services, the rights of the subscriber are exhaustively listed, but at the same time, Article 19 of the same Rulebook lists also the obligations of the operator/provider of services. Particular issues of regulation are the subscriber contracts that the users conclude with the operators/service providers for access to the services. The contracts offered by the operators should be clearly compiled and written so that the ordinary consumer can understand them in order not to misuse the ignorance of the consumer. Users face a large amount of complex information when signing mobile phone deals, phone lines, and online products and services. Various protection measures are applied to ensure that users receive clear, accurate and complete information and that the contracts they sign are justified. Subscription contracts should not contain dishonest conditions or provisions that cause significant imbalance in the rights and obligations of the contracting parties, and to the detriment of the subscribers. Whatever the form of the agreement, consumer protection measures are in place to ensure that suppliers provide sufficient information to their customers and that they use fair terms in the contracts, but although some users sign individual supply contracts, most contracts are pre-arranged by the providers of electronic communication services so that users do not have many opportunities to change them, which leads to the endangering of their rights.

\section{REGULATORY BACKGROUND}

\section{Need for approval of a standard subscriber contract and control of the contract}

The legal basis for the approval and control of the standard subscriber contracts of the operators is given in Article 8 of the existing LEC, which defines the competences of the AEC. Namely, in paragraph 13 of the same article, it is determined that the AEC approves and controls the subscriber standard subscriber contract.

The approval of standard subscriber contracts on the basis of which individual subscriber contracts are made by operators with consumers for access and use of publicly available electronic communications services is an activity implemented by AEC in the last 7-8 years. In the LEC enacted in 2005, which was fully harmonized with the regulatory framework for electronic communications networks and services of the European Commission, AEC did not have competence to approve the standard subscriber contracts. Having in mind all the problems in this domain, the European Commission in 2009 amended the Universal Service Directive and Rights of End Users [7-9], which allowed greater competence of the relevant regulatory bodies in the field of electronic communications, greater rights of end users and obligations of operators for compulsory elements of subscriber contracts, the duration of the same and the volume of information and data publicly available to subscribers published by the operator. Both the services and the volume of information and data are publicly available to subscribers published by the AEC. Following the adoption of this Directive, AEC partially harmonized the ECC in 2008 , on the basis of which standard subscriber 
contracts became subject to prior approval by the AEC. In 2014, the adoption of the LEC envisaged the compulsory elements of the Agreement as well as control over its implementation. Namely, in addition to approving the contracts concluded by the users with the operators, AEC also performs control over their implementation by performing expert supervision through persons authorized to perform expert supervision. In this regard, we note that in the part of the penalty provisions, fines are provided for a committed misdemeanor if the operator does not harmonize the standard subscriber contract in accordance with the conditions in the law.

\section{Agreement for connection and use of a public communication network and/or publicly available electronic communications service}

One of the basic user rights in establishing a subscriber relationship with the operator is the right of the user to conclude a Contract for connection and use of a public communication network and/or publicly available electronic communications service. A consumer or end-user who requires connection and use of a public communications network and/or publicly available electronic communications services has the right to conclude a contract with an operator for connection and use of a public communications network and/or publicly available electronic communications services. The agreement should be in a clear, comprehensive and easily accessible form, and in particular should include: the name and address of the operator; the services to be provided, including in particular information on whether the service is provided for emergency call services and location information of the person making the call, as well as any restrictions on the provision of the service for access to emergency call services in accordance with LEC, information on all other conditions that limit the access and/or use of services and applications, in accordance with the LEC or other law, information on the minimum level of quality of the service provided, in particular the time limit for the initial locking and, where appropriate, other service quality parameters in accordance with Article 109 of the LEC, information on any procedures established by the operator for measuring and shaping traffic in order to avoid overloading of the network connection, as well as information on how these procedures would affect the quality of the service, the types of maintenance services, and the services provided to support users, as well as the ways of establishing contact with these services and any restrictions imposed by the operator in possibility for the subscribers to declare their inclusion of their personal data and which of them will be included in telephone directories and telephone information services in accordance with Article 112 of the LEC; information on prices and tariffs, the manner of obtaining up-to-date information on all applicable tariffs and maintenance fees, as well as possible payment methods, including all differences in costs arising from possible payment methods; the duration of the contract and the conditions for renewal and termination of the services and the contract, including: minimum service deadline under promotional terms determined with special offers, all charges related to number portability and other identifiers and all fees arising from termination of the contract, including cost recovery in respect of terminal equipment; all ways of compensation and refund of money in case of failure to meet the agreed level of quality of the service provided; procedure for resolving a complaint pursuant to Article 53 of the LEC; all types of activities that the operator can undertake in order to preserve his safety or integrity in response to incidents, threats and injuries in accordance with the LEC; manner of informing the subscribers of the planned changes in the conditions specified in the agreement and the manner of accepting the new terms for the extension or termination of the contract; procedures in case of non-payment or untimely payment of the fee for the services; information specifically intended for persons with disabilities and other provisions in agreement with the subscriber.

It can be noted that the new law defines in more details the mandatory elements that should be included in the contract concluded between an operator and a consumer or end-user who requires connection and use of a public communication network and/or publicly available electronic communications service. The contract should also contain provisions that the subscriber must be informed of any proposed changes in the terms and conditions specified in the contract within a period not shorter than 30 days before the introduction of the changes, as well as for the right that in the same period, without notice or consequences, the user can terminate agreement if it does not agree with the proposed changes. The operators are obliged to keep records of all established subscriber relations (postpaid and prepaid), which should in particular contain data on the name, surname and address, and for the legal entity, the name and head office of the legal entity and the personal identification number or number of the passport, the legal entity tax number of the legal entity. The data listed in the records for all established subscriber relations (postpaid and prepaid) are kept 
for a period of one year from the day of issuing the last subscriber's account for the services provided.

The law stipulates that the initial agreement, if it is concluded at a certain obligatory time, must not be longer than 24 months. In any case, the subscriber must be given the opportunity to conclude a contract with a duration not exceeding 12 months.

\section{Dishonest provisions in subscriber contracts}

Subscription contracts should not contain dishonest conditions, that is, provisions causing significant imbalance in the rights and obligations of the contracting parties, to the detriment of the subscribers. The following provisions are considered as dishonest:

- possibility for collection of re-connection fee in case when it is due to the fault of the operator;

- possibility for temporary interruption in the provision of services or termination of the subscriber contract, if the subscriber violated the provisions of another contract concluded with the same operator;

- the possibility of avoiding or limiting the fulfillment of contractual services, to the detriment of the subscriber;

- the possibility of using the public communication service to be conditional on use of any other service or equipment necessary to provide the requested service;

- possibility for payment of services that are not used by the subscriber, referring to the monthly fees for the services that the subscriber will not use for termination of the subscriber contract.

\section{Transparency and publication of information}

Operators shall be obliged to publish transparent, comparable, appropriate and up-to-date information on applicable prices and tariffs, for all fees in case of termination of the contract, as well as information on the general conditions regarding the access and use of the public communications services they provide.

AEC bylaws prescribe in more details the type and content of the data that the operators are obliged to publish. Thus, among other things, mandatory information to be published by operators is:

- information on the applicable tariffs for numbers from the Numbering Plan or value-added services;
- information on any change regarding the access to emergency services or location information of the person making the call-in connection with the service for which the contract was concluded;

- information on any change in the conditions limiting the access and/or use of services and applications, in accordance with the law;

- information on any procedures established by the operator for measuring and shaping traffic in order to avoid overloading or overloading the network connection, as well as information on how these procedures would affect the quality of the service;

- information on subscribers for their personal data to be included in telephone directories and telephone information services;

- regular information on subscribers with disabilities for the products and services intended for them;

- the most commonly used ways of using electronic communications services for committing illegal activities or spreading harmful content, especially when this may affect the rights and freedom of others, including infringement of copyright and related rights and the legal consequences thereof; and

- ways to protect against risks for personal safety, privacy and personal data using electronic communication services.

\section{Number portability}

Number portability is the right of all subscribers to public telephone services (fixed or mobile) to retain the number regardless of the operator providing the service. All operators that provide public telephone services (fixed or mobile) are obliged to provide their subscribers with number portability. The numbers are not transferred from public fixed communications networks to public mobile communications networks and vice versa. The transfer of the number and its activation in the network of the other operator must be carried out as soon as possible. Termination of the service in the procedure for transferring the number must not last longer than one working day. The operator may charge operators and subscribers or operators with a one-time amount for the transfer of the numbers to another operator for covering the costs of transferring the number. The single amount for covering the number 
transfer costs should be foreseen in the interconnection agreements, and the direct (administrative) costs, if any, and charged to the subscribers, must not be dissuasive to use this service. Operators are obliged to bear the cost of adapting their networks to enable number portability and maintenance costs for such assets.

\section{Right to complaint and lawsuit}

Subscriber has the right to submit to the operator:

- a complaint regarding the provision of the services;

- an objection to the amount for which the service is provided;

- a discussion about the quality of the service provided, and

- a complaint for violation of the provisions of the concluded contract for connection and use of a public communication network and/or publicly available electronic communications service.

The complaint is submitted by the subscriber to the operator in writing. The complaint must contain the facts and evidence on which it is based. A subscriber can file a complaint within 15 days from the date of the violation. In a case of submitting a complaint, the operator must check the amount charged to the subscriber or the quality of the service provided, and on the basis of the administrative and/or technical check carried out, confirm the amount or quality of the service provided. In the case of refusal of the complaint as unfounded, the operator shall be obliged to issue a certificate to the subscriber for the performed verification with accurately and clearly stated elements of the administrative and/or technical check. The operator is fully responsible for the authenticity of all allegations given in the certificate. If the subscriber submits an objection to the operator and then a request for a dispute addressed to AEC regarding the amount of the account, the operator may not act in accordance with Article 102 paragraph (1) of the Law on Electronic Communications until the final decision is reached in the procedure for settlement of a dispute, and the subscriber is obliged to pay the amount of the monthly subscription within the set deadline. If the subscriber fails to pay the amount of the monthly subscription within the determined deadline, the operator has the right to act in accordance with Article 102 paragraph (1) of the LEC. If the operator has already interrupted the provision of the subscriber service or disconnected the subscriber terminal equipment from the electronic communications network, prior to receiving the notification from the subscriber or AEC that a dispute settlement procedure has been initiated, it shall be obliged to reconnect without delay and to extend the provision of the service until the end of the dispute settlement proceedings before the AEC, except in cases where the subscriber has terminated the contract. If it is established that the operator violated the provisions of the concluded contract or unjustifiably interrupted the provision of the service to the subscriber who filed a complaint due to violation of the provisions of the concluded contract or complaint for undue interruption in the provision of the service, the subscriber has the right to terminate the contract without compensation, as well as the right to recover all unjustifiably collected funds. The operator shall be obliged to submit to the subscriber a written reply on the merits of the submitted complaint within 15 days from the date of receipt of the complaint. If the subscriber is not satisfied with the decision taken, he/she shall have the right to submit a request for resolving a dispute in accordance with Article 53 of the LEC, within 15 days from the day of its receipt to the AEC. If the operator fails to act upon the complaint within the set deadline, the subscriber has the right to submit a request to the AEC to resolve a dispute within 35 days from the day the complaint was submitted to the operator. Furthermore, the procedure continues as a procedure for resolving a dispute upon request by a user of public electronic communication services.

\section{COMPARATIVE ANALYSIS OF SUBMITTED REQUESTS FOR RESOLVING DISPUTES (COMPLAINTS) FROM USERS BY SERVICES AND OPERATORS FOR THE PERIOD 2011-2016}

In this section, a comparative analysis will be presented regarding the submitted requests for resolving disputes or complaints from users. The analysis presents the situation for various services and existing operators offering those services, for the period 2011-2016.

From Figure 1, it can be noted that in 2009 there were only 102 complaints from users with a tendency to increase the number of complaints in the years to follow so that the culmination can be noticed in 2014 with a total of 2130 user complaints. This is due to the fact that during the period 20122014, AEC conducted a promotional campaign of its competencies, especially in the part intended for protection of the rights of users of public electronic 
communication services in order to educate them as well as promotion of the Contact Center 190. Hence, it was noted that the campaign positively influenced the awareness of the citizens in Macedonia regarding the existence of protection of their right due to dissatisfaction with the services of the operator. Therefore, we believe that the increase in the number of requests to resolve disputes from users was as a result of the successful promotional campaign. After this period, there is a decline in the number of requests for dispute settlement: in 2015, a total of 1760 requests were submitted, and 918 in 2016, which is $50 \%$ less than the previous year. The significant reduction in the number of requests for resolving disputes submitted by the users became due to the establishment of an order in the sphere of dispute resolution in this period. It is important to mention the adoption of the new Law on Electronic Communications in 2014, as well as the bylaws that regulate the matter affecting the end users.

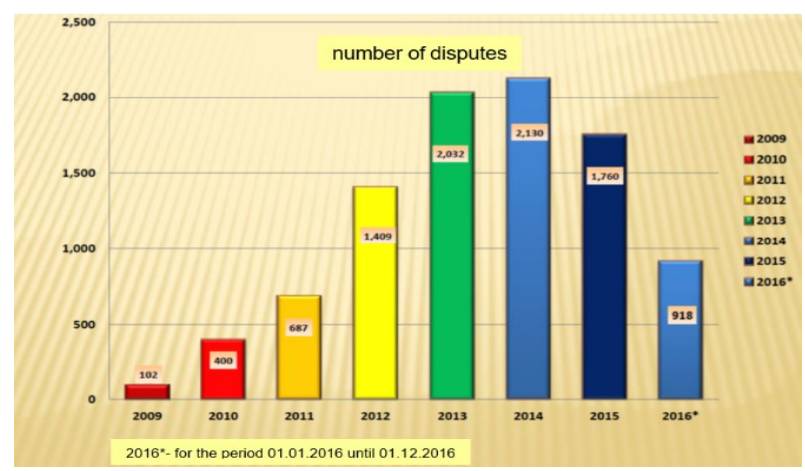

Fig. 1. Number of disputes (for period 2009-2016)

In Figure 2, the end user dissatisfaction of the quality of the services in year 2016 is presented, where it can be noticed that the most requests submitted by end users are related to resolve the dispute due to dissatisfaction in the mobile voice service $(20.2 \%)$, then for mobile Internet (18.1\%), while the smallest part is for the number portability service $(1.9 \%)$.

From Figure 3, it can be noticed that the majority of the submitted requests for resolving the dispute submitted by end users in 2016 belong to the two largest operators in Macedonia (Makedonski Telekom and One.Vip): $50.7 \%$ are related to Makedonski Telekom, $41.7 \%$ on One.Vip and $7.6 \%$ to all other operators in Macedonia.

Figures 4 and 5 show that out of 369 submitted requests for resolving a dispute in the operator Makedonski Telekom, only $14.2 \%$ were adopted or partially adopted, but $47.8 \%$ were rejected. The rest of them were either stopped (13.4\%) or still ongoing (19.1\%). Regarding the type of complaint, most frequently the users sent requests for dissatisfaction for the mobile voice service $(24.1 \%)$, mobile Internet service $(13.3 \%)$ and IPTV (11.1\%).

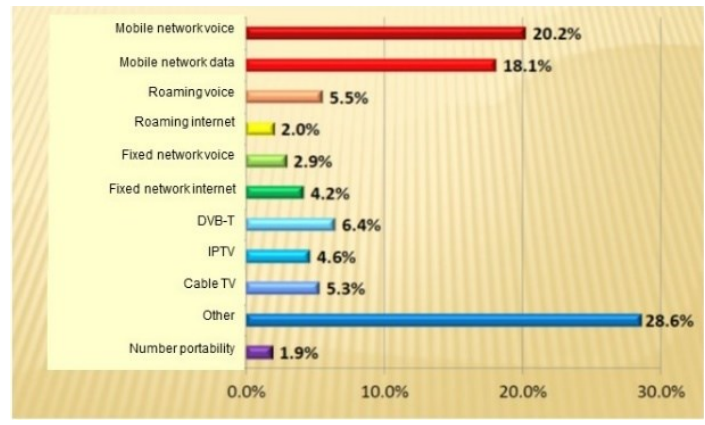

Fig. 2. Disputes from end users (by services, in 2016)

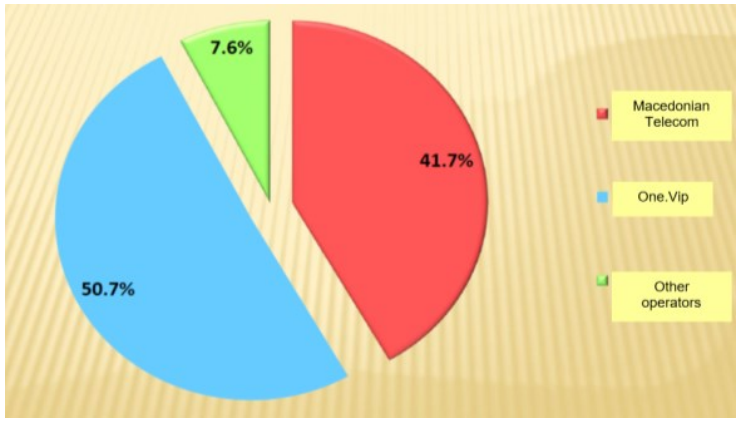

Fig. 3. Disputes from end users (by operators, in 2016)

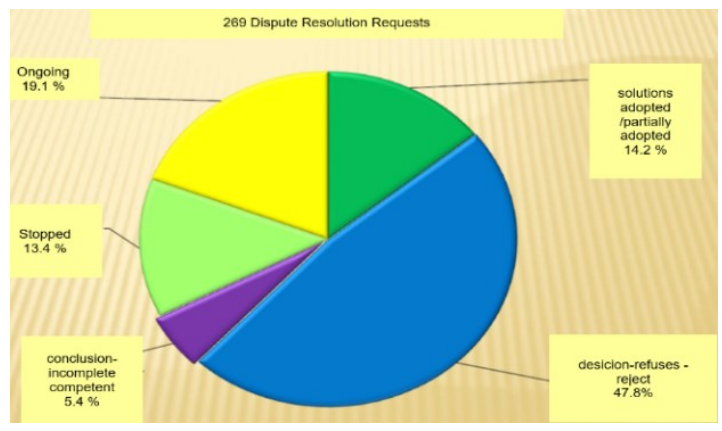

Fig. 4. Status of dispute resolution requests to Makedonski Telekom (369 in total in 2016)

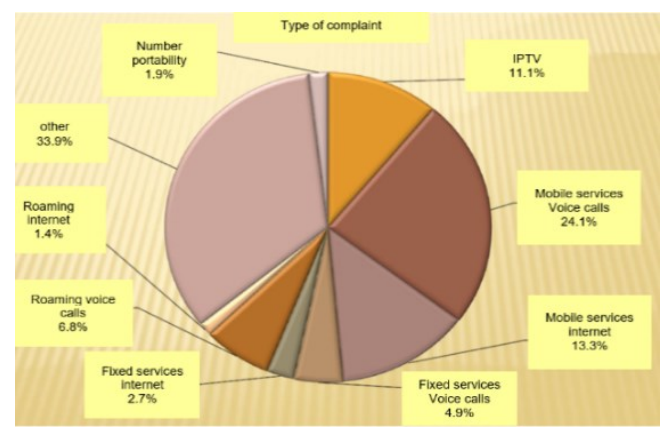

Fig. 5. Distribution of dispute resolution requests to Makedonski Telekom (by type of service) 


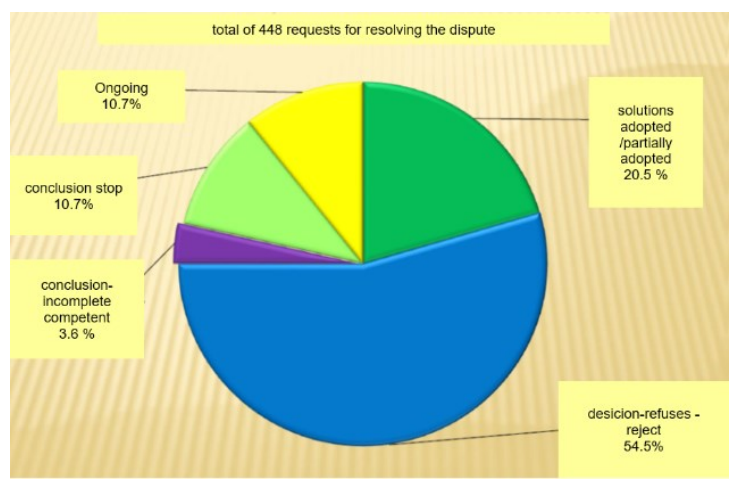

Fig. 6. Status of dispute resolution requests to One. Vip (448 in total in 2016)

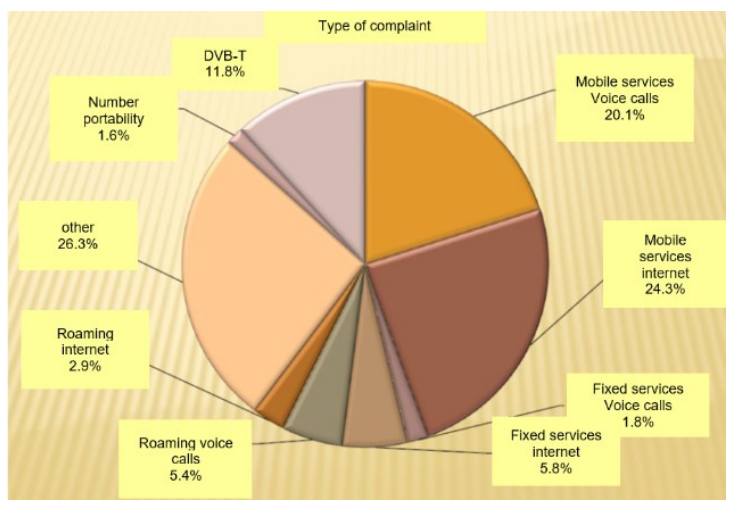

Fig. 7. Distribution of dispute resolution requests to One. Vip (by type of service)

From the graphs, it can be noted that in the two largest operators in Macedonia (Makedonski Telekom and One.Vip) in 2016, the most submitted requests for resolving disputes was about dissatisfaction with the use of the services in mobile telephony and internet services. In the part of the dispute resolution procedure, it is noticeable that $14.2 \%$ were positive/partially accepted requests for resolving a dispute in Makedonski Telekom, and 20.4\% were positive/partially accepted requests for resolving the dispute in One.Vip. The fact that nearly a half of the user requests were negatively resolved should not be disregarded and should be further analyzed. This means that citizens of Macedonia file a large number of complaints that are not justified. On the other hand, there is a reduced number of the total number of complaints filed annually as a result of the citizens' awareness of the unjustified filing of complaints. However, the percentage of unreasonably submitted requests for resolving disputes from the total number of submitted requests is still high on an annual basis. One of the reasons is the insufficient information to the users about their rights arising from the concluded contract that can be considered as insufficient awareness of the citizens about the obligations they undertake with the conclusion of the contract. As mentioned earlier, users face large amount of complex information when concluding the contract, so there is a possibility that some of the users still do not (or not even try) to understand completely the provisions stipulated by the contract, although the operators are obliged to offer contracts which are clearly compiled and written so that the ordinary consumer can understand them. In order to avoid such situation, it is obvious that the users should be more informed not only about their rights and obligations (stipulated by the contract after it is concluded), but also about the electronic communication technologies and services.

\section{Protection and promotion of the rights of end users of public electronic communication services I (law on consumer rights protection and the role of the consumers organizations)}

In the Law on Consumer Protection, the consumer and his rights occupy a central place. Consumer is any natural or legal person who buys products or uses services for direct own consumption for purposes that are not intended for performing his professional occupation or for other business activities.

The main objective of the Consumer Organization is the promotion of consumer protection in order to realize the fundamental rights of consumers. The Consumers' Organization of Macedonia $(\mathrm{COM})$ is constantly working to represent the interests of consumers in the Republic of Macedonia and cooperate on a regional and international level, raising public awareness through informing and educating citizens-consumers, creating and implementing appropriate legislation and consistent consumption politics. For this purpose, COM prepares various brochures, manuals, infotheques and studies, and organizes debates, consultations as well as various other ways and events for educating and informing citizens about their rights as consumers in different areas.

The brochure is of great importance to consumers as a tool for quick and useful information, a set of numbers to a list of competent institutions working in the field of consumer rights protection. This brochure was promoted on December $21 \mathrm{st}$ 2016 at the "City Mall" where a large number of brochures were distributed to the citizens attending the promotion. Previously, a workshop was held entitled "Legal Regulation and Consumer Protection Policy in the Republic of Macedonia and the EU", which discussed the topics of the brochure with experts in this field. 
The brochure presents the Agency for Electronic Communications as a place where the citizens can address if they are dissatisfied with the use of the telecommunication services, that is, on the phone number 190 for the beneficiaries with a note if the problem has not been resolved by the service provider previously. COM prepares studies on various topics. The study "Consumers' Associations in the system of consumer protection-guidelines for improving their position in the Republic of Macedonia" was published in 2016 [10]. This study on improving the position of consumer associations in the system of consumer protection in Macedonia identifies challenges and offers solutions for devising new provisions for consumer associations in the legal framework, as well as for promoting cooperation between consumer organizations, local, national authorities and the business sector in the creation and implementation of consumer protection measures. The aim is to improve the protection, representation and advocacy of consumer interests by consumer associations in Macedonia, in accordance with the policies and solutions of the European Union. Based on the analysis, conclusions are drawn on the situation in Macedonia, of which it is more important that the legal framework in Macedonia does not offer a sufficient basis for consumer associations to be precisely identified and distinguished from other associations, including in terms of avoiding conflicts of interest and before the acquisition of the status of organizations of public interest, the support of the state for consumer associations is insufficient in terms of covering operational costs and capacity building, the legal framework does not regulate fully the issue of representation of collective interests of consumers by consumer associations, etc. It is necessary to take into consideration the best practices abroad especially the successful experiences in the neighboring countries such as Croatia and Serbia and to implement in Macedonia whose experiences point to good cooperation and successful complaint system in which three sectors participate in a coordinated manner: consumers, consumer associations and the state administration bodies. Accordingly, the experience of Croatia in the field of telecommunications is particularly emphasized.

COM conducts consumer consultations. According to the Consumer Consultation Report of Consumers of the COM for 2016, it was found that the highest number of advices was given in connection with telecommunication services, as can be seen from the review below, shown in Table 1.
$\mathrm{T}$ a b l e 1

Review on public services (\%)

\begin{tabular}{|c|c|c|c|c|c|c|}
\hline $\begin{array}{l}\Xi \\
0 \\
\frac{0}{0} \\
\stackrel{0}{\oplus}\end{array}$ & $\begin{array}{l}\vec{D} \\
\vdots \\
0 \\
0\end{array}$ & $\stackrel{000}{\stackrel{\Xi}{\Xi}}$ & $\begin{array}{l}\frac{\bar{d}}{\bar{c}} \\
\overrightarrow{3}\end{array}$ & 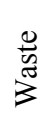 & 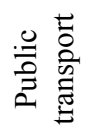 & : \\
\hline 37 & 17 & 12 & 18 & 3 & 8 & 5 \\
\hline
\end{tabular}

According to the report, problems with telecommunication services started at the beginning of the year 2016 when certain operators abolished some of the television programs that the users had until then, and only a few months ago they offered the users to extend the contract for an additional 2 years, without reported that by the beginning of 2016 there will be a larger change in the channels they will receive in the program package. The users dissatisfied with the decision of the operator to replace the channels with others or to reduce them, demanded the termination of the agreement, but there was no legal possibility for termination without paying penalties, because the channels were not part of the user agreement. Because of this situation, AEC concluded that the users were in a disadvantaged position and enabled them to terminate the contract without paying penalty/ penalties, and additionally the operators are obliged to conclude a new agreement with the user in which the full list of channels will be inserted, thus creating a basis for termination of the agreement if one-sided change of the list of channels is made.

From the Tables 2 and 3, we can conclude that the telecommunication services received the most advices regarding the mobile telephony. In mobile operators, the problems were mostly for high bills, that is, additional expenses for prize games, roaming or internet (in the country and abroad).

Table 2

Telecommunication services (\%)

\begin{tabular}{cccc}
\hline $\begin{array}{c}\text { Mobile } \\
\text { telephony }\end{array}$ & $\begin{array}{c}\text { Fixed } \\
\text { telephony }\end{array}$ & $\begin{array}{c}\text { Internet } \\
\text { providers }\end{array}$ & Television \\
\hline 35 & 20 & 21 & 24 \\
\hline \hline
\end{tabular}

$\mathrm{T}$ a b 1 e 3

Mobile services (\%)

\begin{tabular}{ccc}
\hline \hline Contracts & Bills & Other \\
\hline 23 & 52 & 25 \\
\hline \hline
\end{tabular}


Consumers complained that they received rewarding games for which they never signed up, and that they receive high bills with costs for those calls or messages, even if they did not ask for such a thing.

They demanded that these numbers must be blocked and a way to stop messages was found, because the usual commands by sending "S" or "STOP" did not always work. Regarding this problem, COM has appealed to consumers to be careful when using the mobile phone, especially when it comes to a smart device. Namely, they should be aware that by giving the device to their child to use or anyone who does not know how to handle the device, all the clicks that can cause costs will be paid by themselves, as responsible persons for the device.

There were also complaints from consumers living in rural areas complaining of poor reception of the network, or connecting to other roaming networks. According to the report, consumers complained about a high-cost internet usage abroad. Regarding these problems, COM has appealed to consumers that the use of additional roaming and internet services can be completely excluded by requesting to the operator, and thus they will be sure that they will not bear the costs for these additional services.

In the following, we present few tips for consumers regarding the membership in COM and preventive measures that the consumer can take for own protection against possible dishonest provisions:

- Becoming a member of COM: Membership in the COM is very simple and accessible for all consumers in Macedonia. This is done by filling an application form and submitting it to the COM office, but the same can be done electronically.

- Benefits from membership in COM: Apart from the phone counsel you receive and if you are not a member of the COM, you also receive help and support in solving your consumer rights issues. Also, on your request you can get brochures and guides to get more information about your consumer rights. Through your email address you will be notified of major events, changes and innovations in the field of consumer protection.

- Careful reading of the provisions when concluding the consumer contract, with considerable attention to the obligations imposed on the consumer, considering the special position of the consumer as a favored party in the consumer contracts.

- Consulting the consumer organization of the Republic of Macedonia (either on their website www.opm.org.mk or on the addresses and telephone numbers for each of the local representative offices in Skopje, Bitola, Štip, Ohrid, Kočani and Tetovo).

- Consulting an expert (a lawyer, an economist or other expert with knowledge in this field) or appointing such a person as an attorney for concluding a consumer contract.

\section{CONCLUSION}

Macedonia strives for consistent monitoring of the regulation in the telecommunications sector as well as its implementation in the national legislation. The implementation is expected to improve the market in Macedonia in this segment, to ensure greater competitiveness and protection of users, as well as greater protection of children from abuse on the Internet, better telecommunication sector by better regulating the spectrum, etc. There is no doubt that there is progress on the market for electronic communication services in Macedonia. Reducing the barriers to introduction of new entrants to the market, and the introduction of free competition enabled users of public electronic communications services to select an operator who will provide them with the required services. AEC undertook a series of activities that imply the promotion of the end-users rights of public electronic communication services, including persons with disabilities, elderly people and persons with special social needs, such as: operator's choice of price and quality, number portability, promotion of the rights and benefits arising from the universal service, introduction of digitalization in Macedonia, provision of $3 \mathrm{G}$ and $4 \mathrm{G}$ technologies, regulation (reduction) of the prices of the services in roaming of public mobile communications networking and services, implementation of the digital agenda 2020, specifying the procedure for objections from end-users and enabling mediation procedure before submitting a request to resolve a dispute in the AEC and a series of activities related to the transparency of data published by the operators in related to the price and quality of services for the full and timely information to the users of public electronic communication services. In this regard, AEC has created several tools and reviews intended for end-users through which they have been provided with information and education about the services offered by the operators of public 
electronic communications services. Furthermore, through promotional campaigns, AEC educates end users for their competence as well as their rights. Among other things, it pays particular attention to the efficient conduct of the legal procedures envisaged in the LEC, in particular the procedure for acting upon the requests for initiating a dispute submitted by the end users, by introducing a separate customer care service, a free telephone number 190 to which the users may receive information and answers to their questions, as well as a separate service for the receipt of the documentation they attach in order to help end users in exercising their rights. But, according to the statistics presented above, it can be noticed that users still submit a large number of unfounded complaints. Because of this, despite the efforts of AEC for protection and promotion of the rights of the end users, there is still a small degree of backwardness in this part, which is primarily due to their education and assistance in concluding contracts, undertaking obligations, conducting of administrative and judicial procedures. Cooperation and coordination are needed with the Consumers' Organization of Macedonia and the consumer associations that will be more involved with their activities in this sector. This can be achieved by aligning the legislation with the EU regulations, so we strongly believe that it is necessary to follow the example of Croatia, Serbia and Montenegro to harmonize the Consumer Law with the EU directive from 2009 on administrative court measures and collective representation to the interests of consumers, which will create conditions for collective protection of the interests of consumers through out-ofcourt procedures that will be initiated by consumer associations. Consumer associations and consumer organization of Macedonia with acquired status of organizations of public interest and collective representation of consumers will enable advocacy of the interests of end users in the legal procedures before the regulator. Considering that the consumer organization of Macedonia and the consumer associations, besides other authorizations, had exclusively an advisory competence to consumers there is a lack of their authorization to represent the end-users before the administrative bodies and the judicial authorities, which would reduce the ungrounded objections, there would be concluded contracts that will not mislead or disadvantage, the mediation procedures would be more successful and the court proceedings would benefit the users in a larger number. With the possibility of collective advocacy, the costs for the administrative and court fees will be reduced.

\section{REFERENCES}

[1] European Commission's Progress Reports on Macedonia in the process of Euro-integrations for 2008, 2009, 2010, 2011, 2012, 2013 and 2014.

[2] Law on Telecommunications, Official Gazette of RM 33/96, 17/98, 28/00, 04/02, 37/04.

[3] Law on Electronic Communications, Official Gazette of RM 13/05, 14/07, 55/07, 98/08, 83/10, 13/12, 59/12, 23/13.

[4] Law on Electronic Communications, Official Gazette of RM 39/14, 188/14, 44/15, 193/15.

[5] Agency for Electronic Communications, www.aec.mk

[6] Law on Consumer Protection, Official Gazette of RM 38/04, 77/07, 103/08, 24/11, 164/13).

[7] Directive 2002/19/EC of the European Parliament and of the Council of 7 March 2002 on access to, and interconnection of, electronic communications networks and associated facilities (Access Directive).

[8] Directive 2002/20/EC of the European Parliament and of the Council of 7 March 2002 on the authorisation of electronic communications networks and services (Authorisation Directive).

[9] Directive 2009/140/EC of the European Parliament and of the Council of 25 November 2009 amending Directives $2002 / 21 / E C$ on a common regulatory framework for electronic communications networks and services, 2002/19/EC on access to, and interconnection of electronic communications networks and associated facilities, and 2002/20/EC on the authorisation of electronic communications networks and services.

[10] Study on Consumers' Associations in the system of consumer protection-guidelines for improving their position in the Republic of Macedonia, Consumer Organization of Macedonia 2016. 